\title{
PENGGUNAAN COMPUTER BASED-TEST. DI INDONESIA: UTOPIA ATAU KENISCAYAAN?
}

Arief Fahmie

\begin{abstract}
The use of computer technology in psychology has been increasing rapidly. Commonly, computer is used at research activities, exspecially for analizing data. Computer using should be increased in application of psychology in indonesia. in other countries, many psychologists are using computer when they are testing, councelling, or building research (not only for analizing data). Computer-based test is one of applied technology in psychological testing. Actually, the application of computerbased test has big opportunity in Indonesia because people have good appreciation on computer technology development, and they use computer in some activities. Amount of CPU (Computer Personal Unit) has been increasing both in institutes of education and government, as well as in bussiness organizations. On the other hand, there are some problems in applying computer-based test which must be solved. Breaking the intellectual rights is the big difficulty to protect the new technology. Government must uphold the laws. The other problem is innovation of psychologists both on academic and application area at low degree. if must be developed with personal way as well as organizational way continousiy. If it can not be conducted, developmental of psychology in Indonesia will be left behind rather than the other countries.
\end{abstract}

\section{A PENGANTAR}

Sesuai dengan perkembangan ilmu dan teknologi yang cepat, maka penggunaan teknologi informasi telah merambah seluruh kehidupan manusia. Tappscott dalam Ancok (2000) mengemukakan bahwa keterlibatan teknologi informasi dalam kehidupan manusia sangat besar, misalnya perancangan dan pembuatan produk, proses kerja, pusat informasi yang digerakkan oleh komputer. Di sektor bisnis telah banyak penggunaan komputer sebagai perangkat untuk mengakses internet sehingga muncul e-banking. Sampai dengan Februari 2002, telah terdapat sembilan bank yang membuka fasilitas tersebut (Internet, 2002). Di akhir 2002 bahkan muncul layanan perbankan yang menggunakan SMS (short message service) atau mobile banking. Demikian pula di sektor pendidikan, Universitas Islam Indonesia 
Yogakarta telah banyak aplikasi teknologi informatika yang digunakan dalam proses administrasi, misalnya SIMAK (Sistem informasi Manajemen Akademik) atau LIA (Layanan Informasi Akademik).

Di bidang psikologi, baik secara aplikatif maupun teoritis, penggunaan teknologi internet telah berkembang dengan pesat. Barak (1999) menjelaskan bahwa aplikasi teknologi tersebut adalah sebagai sumber informasi tentang konsep dan isu yang mutakhir tentang psikologi, panduan menggunakan aplikasi untuk membantu diri sendiri, testing, informasi tentang pelayanan psikologi, konsultasi dan terapi lewat email atau chatting, web telephony, dan videoconferencing baik secara individual maupun kelompok, dan riset.

Salah satu penggunaan teknologi internet di bidang ilmu psikologi yang menarik untuk dikaji lebih lanjut adalah dalam pengukuran psikologis. Schmidt dan Statonton pada akhir 90-an memprediksikan dalam mengatakan bahwa penggunaan komputer dan internet dalam testing dan asesmen akan meningkat pesat (Ployhart, 2002). Hal ini terbukti pada saat ini, di negaranegara maju aplikasi psikologi yang memanfaatkan teknologi informasi begitu pesat berkembang, misalnya Tes Kecerdasan Emosional yang dapat diperoleh dengan downloadpada http:l lwww utne.com/cgi-bin/eg).

Berbeda dengan negara yang lebih maju maka di Indonesia selama ini administrasi tes dilaksanakan dengan paper-and-pencil yang berarti bahwa testee akan mengerjakan psikotes dengan alat tulis (pensil atau pena) di kertas lembar jawaban. Setelah selesai dikerjakan, lembar jawaban tersebut diskor atau diinterpretasi oleh seorang psikolog. Campbell, Welsh, dan Dahlstrom dalam Mcintire dan Miller (2000) mengemukakan bahwa penggunaan komputer dalam pengukuran psikologi telah dilakukan sejak tahun 1970-an. Fenomena tersebut menunjukkan bahwa kurikulum pendidikan psikologi belum mampu memanfaatkan perkembangan teknologi informasi padahal Ancok (2002) mengemukan perlu adanya pergeseran paradigma dalam pengelolaan pendidikan psikologi yang salah satunya adalah kurikulum pendidikan psikologi yang adaptif.

Secara teoritis, computer-based test (CBT) mempunyai keuntungan lebih cepat, objektif, dan fleksibel (Kleinmuntz. dan McLean, 1992). Pendapat serupa dikemukakan oleh Harris, Lievens dan Harris, Schmidt dalam Ployhart (2002) yang mengatakan bahwa tes psikologi yang menggunakan komputer akan meningkatkan efisiensi waktu dan biaya, mengurangi kemungkinan data yang hilang, dapat dilakukan bersamaan dari berbagai lokasi, dan dapat dilakukan skoring dengan cepat. Namun di sisi lain, penggunaan CBT juga mempunyai kendala-kendala yang harus diatasi, misalnya yang dikemukakan American Psychological Association (1985) bahwa tes dan kuesioner yang dipublikasikan di internet banyak yang belum memenuhi standar penyusunan alat ukur psikologis. Standar terse but meliputi konstruksi dan seleksi item, konsistensi internal, reliabilias tes ulang, serta validitas eksternal maupun internal

Bagaimanakah sebenarnya prospek lebih lanjut dari aplikasi CBT? Apa saja kendala yang mungkin terjadi bila CBT dikembangkan di Indonesia? Serta solusi apa yang tepat agar ilmu psikologi di Indonesia dapat lebih memanfaatkan teknologi komputer dan internet dalam 
asesmen psikologis? Pertanyaanpertanyaan tersebut menarik dikaji lebih jauh untuk mendapatkan jawabanjawaban yang tepat.

\section{B. MEMAHAMI CBT}

Computer-based test adalah alat ukur psikologi yang menggunakan komputer dalam proses administrasi, skoring, dan interpretasi, sedangkan paper-and-pencil fest adalah alat ukur psikologi yang menggunakan kertas dan alat tulis sebagai material tes, serta proses skoing dan interpretasinya dilakukan secara manual. Saat ini pada umumnya, praktisi psikologi di Indonesia menggunakan paper-and-pencil testdan sangatjarang. bahkan mungkin tidak ada, yang menggunakan CBT. Sepanjang pengetahuan penulis, wacana tentang CBT pernah dimunculkan di UGM dan Universitas Gunadarma tetapi belum ditindaklanjuti. Penggunaan komputer untuk suatu pengetesan lebih dikenal dalam salah satu tes bahasa Inggris, yaitu TOEFL (Test of English as a Foreign Language). Hal ini tentu saja menunjukkan perkembangan psikologi yang sangat lambat karena di Amerika Serikat pada tahun 1986 telah terdapat 169 vendor yang setiap bulan menyajkan informasi tentang computer-based test.

Bila secara kongkrit CBT tidak ditemui di Indonesia maka hal tersebut tidak menjadi masalah. Berbagai website menyediakan tes dan kuesioner untuk pengukuran psikologis bag penggunanya. Beberapa jenis tes disajikan khusus untuk mengukur aspek-aspek yang spesifik, seperti IQ, sikap terhadap suatu objek, kecerdasan emosional,juga yang bersifat lebih umum, misalnya kepribadian, minat. Di internet dapat terdapat CBT yang sesuai dengan bentuk tes yang asli tetapi ada juga yang hanya versi elektroniknya atau adaptasi dari paper-and-pencil test. Isinya pun ada yang lengkap namun ada pula yang hanya beberapa item.

Pemanfaatan komputer dalam tes psikologi secara lebih terinci dijelaskan oleh Sampson (2002), yaitu untuk administrasi tes, misalnya penggunaan keyboard sebagai alat untuk memasukkan (input) data, penggunaan scanner untuk memasukkan data yang telah tercantum dalam Iembar jawaban, penggunaan keyboand oleh tester sebagai alat untuk menjawab dalam tes psikologi. Di samping itu komputer dapat digunakan untuk skoning, pembuatan profil skor tes, interpretasi naratif, dan interpretasi tes yang berbasis video yang dapat secara langsung mengikuti administrasi tes.

Secara teoritis, computer-based test mempunyai keuntungan lebih cepat, objektif, dan fleksibel (Kleinmuntz dan Mctean, 1992). Secara lebih terperinci, Mclntire dan Miller (2000) membahas kelebihan dan kekurangan dari computer-based test. Kelebihan dari CBT adalah efisiensi, pelaksanaannya dapat dijadwalkan sesuai dengan kebutuhan, dapat dilaksanakan secara individual dalam suasana yang nyaman, memberikan administrasi dam skoring yang standar dan mengurangi human error, mempunyai prosedur testing yang menggunakan teknologi, dan mempunyai kesempatan lebh pada seseorang yang secara mental alau fisik cacat sehingga tidak dapat menggunakan alat tulis.

Bila dikaitkan dengan teknologi internet maka beberapa keuntungan CBT dapat bertambah yaitu dapat diakses oleh berbagai kalangan di berbagai tempat, perbaikan dalam instruksi, item, teknik skoring, dan norma dapat mudah didistribusikan, dan penghematan dalam permbelian materi tes (Barak, 1999). 
Di sisi lain terdapat kekurangan CBT yaitu tidak adil bagi yang tidak mampu mengoperasionalkan komputer atau memiliki fobia komputer, memberikan kesempatan latihan sehingga dapat mengurangi kualitas tes, interpretasi dapat tidak akurat, terdapat kemungkinan tidak equivalen secara psikometrik, tidak memberi kesempatan menggunakan strategi yang sama dengan paper-andpencil test, misalnya tidak boleh melihat item sebelumnya atau merubahnya (Mcintire dan Miller, 2000).

Seiring dengan perkembangan komputer yang luar biasa maka kemungkinan-kemungkinan pengembangan CBT menjadi terbuka luas. Barak (1999) menengarai bahwa CBT dapat dikembangkan dengan penggunaan teknologi tiga dimensi, virtual reality, dan antarmuka grafikal. Sebagai contoh bila aspek yang diukur adalah kemampuan spasial maka pengukurannya dapat dilakukan dengan tes psikologi yang menggunakan teknologi tiga dimensi. Riva dalam Barak (1999) mengungkapkan bahwa penggunaan virtual reality dalam pengukuran psikologis dapat digunakan untuk mengetahui body image seseorang. Demikian pula dengan teknologi videoconferencing yang akan meningkatkan efisiensi dalam pengukuran psikologis terutama berkaitan dengan jarak geografis antara para ahli dengan kliennya. Ball, Scott, McLearn, and Watson dalam Barak (1999) menemukan bahwa pengukuran psikologis pada para penderita depresi, gangguan gerakan, dan schizophrenia dapat dilakukan dengan baik melalui videoconferencing.

Penggunaan CBT memang menjanjikan efisiensi sehingga tidak heran banyak organisasi dan ahli tes psikologi menggantikan paper-and-pencil test dengan CBT (Stanton dalam Ployhart,
2002) karena terdapat keuntungan lebih cepat, objektif, dan fleksibel (Kleinmuntz dan McLean, 1992), namun di sisi lain, penggunaan CBT perlu dikaji terutama dalam hal reliabilitasnya. Hal ini sesuai dengan Guidelines for Computer-Based Testing (Olsen, 2002) yang mengharuskan salah satu standar yang mendasar dari CBT adalah reliabilitas. Senada dengan hal tersebut, APA Guidelines on ComputerBased Tests and inter-pretations (Van de Vijver \& Harsveld; Green dalam Biggerstaff, dkk., 2002) memandang perlu diperhatikan reliabilitas dalam menggunakan $\mathrm{CBT}$. Di samping itu, secara umum penelitian tentang aspek psikometrik CBT perlu diteliti lebih jauh mengingat bahwa hasil-hasil penelitian menunjukkan hasil yang tidak selalu sama (Mcintire dan Miller, 2000).

Secara umum, reliabilitas alat ukur dipengaruhi beberapa faktor. Mcintire dan Miller (2000) mengemukakan bahwa faktor-faktor yang mempengaruhi reliabilitas yaitu tes itu sendiri, administrasi tes, skoring tes, dan orang yang mengerjakan tes. Bila dianalisis lebih jauh dalam konteks penggunaan CBT, maka reliabilitas tes ulang dari CBT dan paperand-pencil test dapat tinggi dengan memperhatikan faktor-faktor di atas. Artinya reliabilitas CBT sebagai adaptasi dari paper-and-pencil test perlu memperhatikan hal-hal berikut:

1. Format tes, misalnya tidak mengubah item-item tes dari paper-andpencil test, tampilan di layar komputer yang tidak menimbulkan kesulitan membaca pertanyaan atau instruksi.

2 Administrasi tes, misalnya diberikan instruksi yang standar, pencantuman instruksi dalam tampilan d komputer, ruang tes yang nyaman (tidak bising, tidak panas) 
3. Skoring tes, yaitu skoring tes harus sesuai dengan perintah of manual tes.

4. Orang yang mengerjakan tes, misalnya tidak mengalami kelelahan, sakit, serta didorong untuk serius dan jujur.

Berkaitan dengan penggunaan komputer untuk pengukuran psikologis maka perlu juga diperhatikan faktor kebiasaan dalam penggunaan komputer. Penelitian yang dilakukan Eastin dan Larose (2000) menunjukkan bahwa individu yang mempunyai efikasi diri yang tinggi akan suka menggunakan komputer untuk mencari data. Secara lebih spesifik Mcintire dan Miller(2000) mengungkapkan bahwa salah satu faktor dalam penggunaan CBT adalah diskriminasi bagi yang tidak mampu mengoperasionalkan komputer atau memiliki fobia komputer. Individu yang dapat mengoperasionalkan komputer akan lebih mudah memahami instruksi yang ada. $\mathrm{Hal}$ ini berkaitan juga dengan kondisi psikologis ketika menghadapi tes. Individu yang memiliki kemampuan mungkin tidak mengalami kecemasan sehingga penggunaan komputer tidak mempengaruhi hasil tes. Penelitian lain ternyata menunjukkan hasil yang berbeda. Clariana dan Wallace (2003) telah meneliti tentang penggunaan komputer dalam mengukur kemampuan kognitif. Hasil penelitian menunjukkan bahwa frekuensi penggunaan komputer tidak mempengaruhi hasil tes, baik disajikan dalam bentuk komputer maupun kertas.

\section{PROSPEK DAN KENDALA PENGGUNAAN CBT DI INDONESIA}

Bagaimanakah prospek dan kendala penggunaan CBT df Indonesia? Sebenamya penggunaan CBT di Indonesia mempunyai peluang yang besar. Hal ini didukung deh faktor apresiasi masyarakat Indonesia yang baik terhadap perkembangan teknologi komputer dan makin meningkatnya jumlah unit komputer, baik di rumah, sekolah, atau perusahaan. Apresiasi tersebut dapat dilihat dari diresmikannya Pusat Komputer Apkomindo Glodok Plaza pada bulan Maret 2003 yang diharapkan dapat menjadi jendela dan barometer bagi perkembangan teknologi informasi di Indonesia (http://www.sinarharapan. co. id/berita/0303/08/eko06. html). Indikator yang lain tentu mudah ditemukan seperti Rencana Strategi Universitas Airlangga 1997-2005 yang mengembangkan Pusat Komputer menjadi Pusat Layanan Informasi (http:/ (www. dikti.org/rens tra/unair. html), maraknya pemerintah daerah mengembangkan e-government (http://www. takalar.goid), jumlah penghuni kamar chatting dari indonesia yang menempati urutan kedua setelah Jepang.

Dari sisi jumlah perangkat keras, telah terjadi peningkatan pembelian unit komputer cukup signifikan di Indonesia. Untuk tahun 2003 saja, diprediksikan penjualan komputer di Indonesia sedikitnya mencapai 720.000 unil senilai US $\$ 20$ juta atau naik 20 persen dibandingkan tahun 2001 , yang penjualannya baru mencapai 600.000 unit senilai US\$ 600 juta (http/ /www.sinarharapan.co.id/berita/0303/ 08/eko06.html). Data lain dari Asosiasi Pengusaha Komputer Indonesia (Apkomindo) menunjukkan bahwa selama triwulan pertama tahun 2003 belanja Personal Computer(PC) sektor pemerintah mengalami kenaikan signifikan dengan menyerap hingga $40 \%$ dan total penjualan sebesar 150.000 unit (http://kominfo.go.id/ berita_detail.asp?id=166). Animo yang 
tinggi dari masyarakat umum untuk memiliki komputer juga terjadi di daerah. Pameran komputer murah yang digelar outlet Sriwijaya Computers (Sriwijaya Comp) diperpanjang karena antusiasme masyarakat terhadap pameran ini. Semula pameran komputerdirencanakan mulai 30 Januari hingga 14 Februari 2003 tapi melihat prospek pasar masih bagus diperpanjang lagi hingga 2 Maret 2003. (http://wwwindomedia.com/sripo/).

Bagaimana dengan kendalanya? Secara umum terdapat dua kendala dalam penggunaan CBT di Indonesia, yaitu masih kurangnya kuantitas dan kualitas penelitian di bidang psikologi. dan lemahnya penegakan hukum, terutama tentang Hak atas Kekayaan intelektual (HaKl). Kedua hal tersebut sebenamya berkaitan sangat erat namun memiliki perkembangan masing-masing.

Pada umumnya alasan utama sebagian besar dosen untuk melakukan penelitian adalah kenaikan pangkal kepegawaian. Selebihnya motivasi dosen melakukan penelitian untuk pengembangan keilmuan yang digeluti jumlahnya paling banyak 10 persen dari total dosen yang melakukan penelitian (Sujanto dalam Kompas, 2003). Kondisi serupa juga dapat ditangkap dari Rencana Strategis Universitas Airlangga Surabaya yang mencatumkan salah satu kelemahan di Universitas tersebut adalah Motivasi dan minat meneliti di kalangan dosen yang masih rendah sehingga dalam Strategi Dasar Pengembangan, masalah penelitian perlu diselesaikan. (http//www, dikti,o[g/renstra/unair,html). Sarlito (Kompas, 2003) mencoba mengimbangi bahwa sebenarnya aktivitas penelitian di lingkungan Fakultas Psikologi Ul cukup banyak. Dari skripsi saja, persoalan yang diangkat sangat beragam, mulai dari persoalan psikolinguistik bayi, sampai psikologi Soeharto. Memang belum pernah ada penelitian yang secara eksplisit menyimpulkan bahwa kuantitas dan kualitas penelitian psikologi di Indonesia rendah tetapi indikator dari laporan Dikti .httg://www diktiorg/o $3 \mathrm{~m} /$ $\mathrm{g} 3 \mathrm{~m} 3 \mathrm{htm}$ ! bahwa bidang ilmu dari kegiatan penelitian Hibah Bersaing I sampai dengan IV menurut konsorsium adalah Pertanian $46 \%$, Teknologi $17 \%$, MIPA $11 \%$, Kesehatan $8 \%$, Pendidikan $7 \%$, Sosial 6\%, Ekonomi 2\%, Hukum, Seni dan Olahraga, dan Psikologi masing-masing $1 \%$ layak digunakan untuk mengambil kesimpulan bahwa memang penelitian psikologi perlu ditingkatkan.

Mengapa mtotivasi untuk meneliti rendah? Persoalannya, menurut Sujanto (Kompas, 2003), dibutuhkan biaya untuk melakukan sebuah penelitian yang berkualitas dan bukan soal yang mudah untuk mencari biaya penelitian di Indonesia. Jumlah anggaran penelitian dari pemerintah minim, sedangkan dukungan dari institusi pendidikan juga kurang. Kondisi ini jelas tidak menarik minat dosen untuk melakukan penelitian yang serius dan membutuhkan waktu lama dengan hasil yang bermutu. Di samping itu, kemampuan dosen tentang metodologi sangat beragam, dan minat untuk melakukan penelitian serius yang menda-lam dan membutuhkan waktu lama masih sangat kecil. Bahkan bagi dosen senior justru sering kali masih disibukkan dengan tugas-tugas keilmuan lainnya daripada melakukan penelitian yang mendalam dan membutuhkan waktu lama.

Penelitian tentang CBT, baik dalam bentuk penelítian dasar maupun terapan, memang menuntut biaya yang besar dan waktu yang lama karena membutuhkan 
infrastruktur dengan biaya yang tinggi dan menyangkut sesuatu yang baru. Dibutuhkan motivasi yang tinggi untuk terus menerus menemukan formula CBT yang valid dan reliabel. Penulis telah mencoba meneliti tentang $\mathrm{CBT}$ dengan membandingkan Tes 16PF dakam format CBT dan PPT. Hasil penelitian menyimpulkan bahwa skor Tes 16PF dalam format PPT dan CBT menunjukkan hasil yang sama pada $M D$, Faktor $A, B, C$, $E, F, G, H, L, O, Q 3$, dan Q4, sedangkan pada Faktor I, M, N, Q1, dan Q2terdapat perbedaan skor (Fahmie, 2003). Di sisi lain, jumlah penelitian berkelanjutan memang minim. Sujanto (Kompas, 2003) menengarai bahwa tidak adanya lanjutan dari sebuah penelitian, memang bisa disebabkan karena tidak adanya minat pada suatu persoalan, atau memang kemampuan dosen itu masih rendah, sehingga sulit untuk melanjutkan sebuah penelitian. Lebih sulit lagi jika muncul pertanyaan: kenapa harus memikirkan tes psikologi yang baru (administrasinya), sedangkan tes psikologi yang sekarang digunakan masih harus dipertanyakan validitas dan reliabilitasnya.

Selain problem berupa motivasi untuk meneliti, masih ada kendala besar yang bersif at ekstemal yaitu perlindungan Hak atas Kekayaan Intelektual (HaKl). Secara umum Hak Kekayaan Intelektual dapat terbagi dalam dua kategori yaitu Hak Cipta dan Hak Kekayaan industri. Hak Kekayaan industri meliputi Paten, Merek, Desain Industri, Desain Tata Letak Sirkuit Terpadu, Rahasia Dagang, dan Varietas Tanaman. Sebenamya proses perlindungan hak-hak intelektual di Indonesia telah menuju arah yang menggembirakan. Diawali dengan keikutsertaan Indonesia sebagai anggota WTO (World Trade Organization) yang mengharuskan Indonesia menyesuaikan segala peraturan perundangannya di bidang Hak Kekayaan intelektual dengan standar TRIP's (Trade Related Aspects of Intel/ectual Property Rights) yang dimulai sejak tahun 1997 dan diperbaharui pada 2000 dan 2001. Hal ini juga akibat dari diratifikasi konvensi-konvensi internasional Hak Kekayaan intelektual dan juga menyesuaikan dengan ketentuan-ketentuan yang diharuskan yaitu Undang-undang tentang Hak Cipta, Desain Industri, Desain Tata Letak SirkuitTerpadu, Rahasia Dagang, Paten dan Merek (http://www.dgip.go.id/ indonesia/pengantar. htm). Direktorat Jenderal Hak Kekayaan Intelektual (Ditjen. HKI) yang berada di bawah Departemen Kehakiman dan HAM Republik indonesia adalah instansi yang berwenang dalam mengelola Hak Kekayaan intelektual di indonesia. Khusus untuk mengelola informasi HKI juga telah dibentuk Direktorat Teknologi informasi di bawah Ditjen HKI. Perkembangan tersebut menunjukkan bahwa pengakuan HKI di Indonesia mendapat perhatian yang serius. (http: $/$ I www. dgip.go.id/ind onesia/ pengantar $2 \mathrm{htm}$ ). Hal ini berarti bahwa seandainya CBT berhasil dibuat dan dipatenkan maka sebenarnya perlindungan terhadap hak ciptanya telah mempunyai payung hukum. Perlindungan yang bersungguh-sungguh atas kekayaan intelektual merupakan hal yang vital bagi pertumbuhan industriTeknologi Informasi di Indonesia. Kepastian hukum akan semakin meningkatkan kepercayaan terhadap suatu sistem di mana inovasi akan mendapat imbalan dan hak atas kekayaan intelektual mendapat penghargaan. Hanya dalam lingkungan semacam itulah industri perangkat lunak lokal dapat fumbuh dan 
berkembang (http: $/ l w w w$. micro soft com/in done sialnews/10.

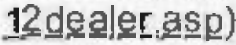

Bila masalah perlindungan hukumnya telah ada maka yang menjadi pertanyaan adalah penegakan hukumnya. Sampai saat ini telah ada beberapa keputusan pengadilan tentang pelanggaran hak cipta. Keputusan Pengadilan Negeri Jakarta Barat pada tanggal 28 September 2001 terhadap Procomm merupakan kasus pelanggaran hak cipta perangkat lunak sejenis yang pertama di Indonesia dan menandai tonggak sejarah baru dalam perlindungan atas hak kekayaan intelektual di Indonesia. Pengadilan Negeri memutuskan bahwa Procomm diwajibkan membayar US\$4,4 juta kepada Microsoft untuk pelanggaran hak cipta. Kasus lain terjadi of Pengadilan Negeri Jakarta Pusat yang pada tanggal 4 Oktober 2001 memutuskan bahwa PT Panca Putra Komputindo (PT Panca), HM Computer (HM), HJ Computer dan Altec Computer yang beralamat di Mangga Dua, Jakarta, telah melakukan pelanggaran terhadap undang-undang hak cipta Indonesia. Pengadilan Negeri Jakarta Pusat memutuskan bahwa keempat dealer komputer ini bersalah telah menginstal kopi yang tidak sah dari perangkat lunak Microsoft Windows dan Microsoft Office d komputer-komputeryang mereka jual ke konsumen. (httte://www.microsoft.com! indonesia/news (10-12deater asp) )

Contoh-contoh tersebut tentu menggembirakan walaupun harus diingat bahwa secara umum penegakan hukum di Indonesia masih lemah. Tidak terbilang analisis para pakar maupun informasi yang disampaikan oleh masyarakat bahwa kualitas keputusan peradilan belum memuaskan rasa keadilan masyarakat. Terlebih lagi dalam kasus HaKI yang terbilang masih baru dalam sistem hukum di Indonesia. Sebagai bahan perbandingan, Business Software Alliance menyimpulkan bahwa pembajakan perangkat lunak adalah isu besar yang dihadapi Indonesia. Menu rut mereka, tingkat pembajakan of Indonesia di tahun 2000 adalah 89 persen, salah satu yang tertinggi di dunia. Pembajakan sebesar ini berarti kerugian sebesar hampir 70 juta dolar AS bagi industri (http:/ /unw, microsoft.com/indonesia /news $/ 10$ 12dealer.asp)

Hal ini tentu menyimpan pertanyaan besarbagi nasib CBT di Indonesia. Bukan tidak mungkin bla akan beredarCBT dalam versi bajakan, seperti nasib program komputeryang lain. Kondisi ini tentu sangat merugikan bag pencipta program tersebut dan akhimya dapat menurunkan motivasi untuk mengembangkan CBT.

Mengembangkan CBT di Indonesia dapatdisikapi dengan optimis dan pesimis. Optimis bila melihat bahwa penggunaan CBT di Indonesia merupakan sebuah keharusan sebagai konsekuensi dari perkembangan teknologi. Psikologi di Indonesia tidak dapat berdiam diri dan hanya menjadi konsumen terus menerus tapi harus dapat bersaing dengan negeranegara lain. Kendala yang ada harus segera diatasi, peluang yang ada harus dimanfaatkan. Sementara yang pesimis sebenarnya tidak boleh disalahkan karena kendala yang ada bersifat sistemik sehingga memerlukan upaya yang sangat keras untuk menguranginya. Terlepas dari optimis atau pesimis namun beberapa upaya dapat dicoba untuk mengembangkan $\mathrm{CBT}$ di Indonesia, yaitu

1. Meningkatkan motivasi bagi peneliti, tidak hanya dosen, untuk mengembangkan CBT baik secara individual maupun institusional, misalnya HIMPSI atau Fakuitas 
Psikologi mengadakan seminar, pelatihan, workshop, atau lomba yang berkaitan dengan CBT.

2 Membangun kesadaran masyarakat umum dan kalangan psikologi akan isu-isu pembajakan dan HaKI melalui seluruh media, salah satu dapat menggunakan www.stopiracy.com, sebuah situs Web yang dimaksudkan untuk meningkatkan pengetahuan tentang HaKl.

3. Memperluas jaringan dengan disiplin ilmu lain, misal hukum dan teknik informasi, sehingga pengembangan CBT menggunakan pendekatan multidisipliner.

4. Memanfaatkan jumlah unit komputer di institusi pendidikan, bisnis, atau pemerintahan yang semakin meningkat untuk digunakan sebagai laboratorium sehingga tidak selalu setiap Fakultas Psikologi harus memiliki laboratorium komputer sendiri.

Uraian-uraian di atas tentu masih sangat mungkin untuk dilengkapi, didebat, bahkan disalahkan, baik sebagian atau bahkan seluruhnya. Satu hal yang penting adalah gagasan yang relatif baru (karena tidak baru sama sekali) memang harus digulirkan. Terlepas dari apakah sikap optimis atau pesimis yang diambil tetapi menanggapi secara tertulis tentu lebih penting.

\section{KESIMPULAN DAN SARAN}

Penggunaan teknologi komputer dalam bidang psikologi telah meningkat sangat pesat namun Di Indonesia, komputer lebih banyak digunakan dalam banyak aktivitas riset. Di negara yang lebih maju seperti AS dan inggris, telah banyak penggunaan komputer untuk aplikasi psikologi, misalnya computerbased test, computer-based fearning.
Penggunaan computer-based test di Indonesia sebenarnya mempunyai peluang yang besar, yaitu apresiasi yang bak dari masyarakat terhadap perkembangan teknologi komputer dan jumlah unit komputer yang makin meningkat. Di sisi lain terdapat sejumlah permasalahan yang perlu diselesaikan yaitu perlindungan terhadap hak cipta dan motivasi meneliti yang masih rendah. Sebagai sebuah perkembangan jaman yang tidak terelakkan maka penggunaan computer-based test di Indonesia perlu lebih dikembangkan jika tidak maka psikologi di Indonesia akan lebih tertinggal.

\section{DAFTAR PUSTAKA}

.2002. E-banking Di Indonesia. Internet. Edisi 15 Januari - 15 Februari 2002.

2003. Glodok Plaza Jadi Barometer Perkembangan $\mathrm{IT}$ di Indonesia. htt $p: / / w w w$. sinarharapan.co.id/berita/0303/08/ eko06. html. 20 Februari 2003.

2003. Pengadilan Indonesia Mengeluarkan Satu Lagi Keputusan Penting Untuk Industri Teknologi Informasi Di Indonesia. Kepercayaan Industri IT Lokal Semakin Kuat Pelaku Diwajibkan Membayar 4,76 Juta Dolar AS Total http://www. microsoft.com/indonesia/news/1012 dealer.asp. 20 Februari 2003.

2003. Pengakuan Hak Kekayaan intelektual (HKI) di Indonesia http://www.dgip.goid/ indonesia/pengantar.htm. 20 Februari 2003. 
2003. Pengakuan Hak Kekayaan Intelektual (HKI) di Indonesia http// www. dgip.go.id/in don esial pengantar2.htm. 20 Februari 2003.

2003. Renstra Universitas Airlangga 1997-2005. http:// www. dikti. org/renstra/unair. html. 20 Februari 2003.

2003. Belanja PC Pemerintah Meningkat Tajam http///kominfo.goid/ berita_detailasp?id=166. 20 Februari 2003.

2003. Pameran Komputer Harga Diskon. http://www. indomedia.com/sripo/. 20 Febru ari 2003

2003. Program Penelitian Hibah Bersaing. http://www. dikti.org/p $3 \mathrm{~m} / \mathrm{p} 3 \mathrm{~m} 3 . \mathrm{html} .20$ Februari 2003.

Azwar, S.1997. Reliabilitasdan Validitas. Pustaka Pelajar. Yogyakarta.

Barak, A. 1999. Psychological applications on the internet: A discipline on the threshold of a new mille n nium. ht $t \rho: / /$ consiructhaila.acill-azy/app-r.htm.

Biggerstaff, S. 2002. Equivalence of the Computer-Based Aviation Selection Test Battery (ASTB). http://www. ijoa.org/imta96/paper 47.html. 30 Oktober 2002.

Clariana, R.B., Wallace, PA.. 2003. PaperBased Versus Computer-Based Assessment: Key Factors Associated with the Test Mode Effect. http:// www personal. psu.edu/faculty///b/ rbc4/test modedoc. 20 Januari 2003.

Eastin, M.S. , LaRose, R. 2002. Internet Self-Efficacy and the Psychology of the Digital Divide. JCMC 6 (1) September 2000 hitp:/ /www ascusc.org/, $\mathrm{cmc} / \mathrm{vol} 6 /$ issuef/ easlin.html. 16 Desember 2002.

Fahmie, A. 2003. Efektivitas Tes 16 PF dalam Format Computer Based-Test untuk Mengganti Format Paper-andPencil Test. Laporan Penelitian (Tidak diterbitkan). Lembaga Penelitian Universitas Islam Indonesia, Yogyakarta.

Kompas. 2003. Penelitian untuk Alasan Kenaikan Pangkat http://www. kompas.com/kompas\%2Dcetak/ 0302/21/dikbud/140917.htm. 20 Februari 2002.

Mclntire, S.A., Miller, L.A. 2000. Foundation of Psychological Testing. McGraw-Hill Companies. Boston.

Olsen, J.B. 2002. Guidelines for Computer-Based Testing. http/// www. isoc. org/oti/articles/0500/ olsen.htmi. 30 Oktober 2002.

Ployhart, R.E. 2002. Web-Based vs. Paper-and-Pencil Testing: Are Test Scores Comparable Across Applicants and incumbents?. hitp:/ /www. isoc. org/oti/articles/0500/ olsen.himl. 30 Oktober 2002.

Sampson, J.P.Jr. 2002. Computer-Assisted Testing in Counseling and Therapy. ERIC Digest. http://www.ed.gov/ databases/ER/C_Digests / ed 391983.htm/. 30 Oktober 2002. 